\title{
Analisis Komitmen Pemerintah Kabupaten Padang Pariaman dalam Mengatasi Masalah Stunting Berdasarkan Nutrition Commitment Index 2018
}

\author{
Merri Syafrina ${ }^{1}$, Masrul $^{2}$, Firdawati ${ }^{3}$
}

\begin{abstract}
Abstrak
Stunting merupakan bentuk kegagalan pertumbuhan (growth faltering) akibat akumulasi ketidakcukupan nutrisi yang berlangsung lama mulai dari kehamilan sampai usia 24 bulan. Padang Pariaman pada tahun 2017 angka stunting adalah $33,6 \%$. NCl adalah indeks untuk mengukur komitmen pemerintah dalam mengatasi kekurangan gizi dengan 12 indikator yang dikelompokkan dalam 3 tema yaitu anggaran, kebijakan program dan hukum. Tujuan penelitian inin adalah menganalisis komitmen Pemerintah Kabupaten Padang Pariaman dalam mengatasi stunting berdasarkan $\mathrm{NCl}$. Penelitian menggunakan metode kualitatif dengan rancangan penelitian studi kebijakan (policy study), dan juga dilakukan skoring serta wawancara pada informan. Jumlah informan penelitian yaitu 11 orang. Analisis data dilakukan dengan triangulasi metode dan triangulasi sumber data. Hasil penelitian dari 12 indikator $\mathrm{NCl}$, total skor adalah 6 diantaranya untuk skor 1 yaitu promosi MP-ASI, kondisi program gizi dalam kebijakan daerah, prioritas gizi dalam perencanaan daerah, koordinasi lintas sektor, target program gizi dan survei gizi. Ada 6 indikator dengan skor 0 diantaranya anggaran program gizi (stunting) yang masih kurang, cakupan Vitamin A belum mencapai terget, cakupan air bersih belum mencapai target, cakupan sanitasi belum mencapai target, kunjungan ibu hamil belum mencapai target dan tidak ada regulasi/hukum tentang perbaikan gizi.
\end{abstract}

Kata kunci: stunting, $\mathrm{NCl}$, komitmen

\begin{abstract}
Stunting is a form of growth failure due to the accumulation of maternal inadequacies in nutrition from 24 years of pregnancy. Padang Pariaman in 2017 the stunting rate was $33.6 \%$. NCl is an index to measure commitment in the context of nutrition with 12 indicators grouped into 3 themes, namely budget, program policy and law. The objective of this study was to analyze the commitment of the Padang Pariaman District Government in overcoming the Nutrition Commitment Index. This study used research methods by using policy studies (policy studies) and also scoring and interviewing informants. The number of research informants was as many as eleven person. Data analysis was carried out by method triangulation and data triangulation. The results of the study from $12 \mathrm{NCl}$ indicators, total scores were six likes for score 1 namely MP ASI promotion, nutrition program conditions in regional policies, key nutrition in planning, health sector programs, nutrition program targets and nutrition surveys. The 6 indicators with a score of 0 that were carried out by the nutrition program budget were still lacking, showing Vitamin $A$ had not reached the target, the clean air range had not reached the target, the sanitation target had not reached the target, the visit of pregnant women had not reached the target and no denial / Law about improving nutrition.
\end{abstract}

Keywords: stunting, nutrition commitment index, commitments

Affiliasi penulis: 1. Prodi S2 Kesehatan Masyarakat Fakultas Kedokteran Universitas Andalas Padang (FK Unand), 2. Bagian IImu Gizi FK Unand 3. Bagian IImu Kesehatan Masyarakat FK Unand Korespondensi: Masrul, Email:masrulmuchtar@yahoo.com Hp: 085355005359

\section{PENDAHULUAN}

Stunting (pendek) merupakan tragedi yang tersembunyi. Hal ini disebabkan karena stunting salah satu masalah gizi yang dapat menjadi ancaman bagi kualitas hidup manusia di masa mendatang. Balita 
atau baduta yang mengalami stunting akan memiliki tingkat kecerdasan tidak maksimal. Menurut WHO, Child Growth Standart stunting didasarkan pada indeks panjang badan dibanding umur (PB/U) atau tinggi badan dibanding umur (TB/U) dengan batas ( $z-$ score) kurang dari -2 SD. ${ }^{1}$

Ancaman permasalahan gizi di dunia adalah terdapat 165 juta anak dibawah 5 tahun dalam kondisi pendek dan 90 persen lebih berada di Afrika dan Asia. Target global adalah menurunkan stunting sebanyak 40 persen pada tahun $2025 .^{2}$

Hasil Pemantauan Status Gizi (PSG) 2015, sebesar 29 persen balita di Indonesia termasuk kategori pendek. Berdasaran kelompok umur pada balita, semakin bertambah umur maka prevalensi stunting semakin meningkat. ${ }^{3}$ Hasil Riset Kesehatan Dasar (Riskesdas) pada tahun 2010 didapatkan prevalensi stunting di Indonesia yaitu 35,6 persen, dimana terjadi peningkatan pada tahun 2013 menjadi 37,2 persen. Prevalensi stunting paling tinggi pada usia 24-35 bulan yaitu sebesar 42 persen dan menurun pada anak usia 36-47 bulan (39,7\%). ${ }^{4}$

Provinsi Sumatera Barat, berdasarkan laporan PSG tahun 2015-2017 terjadi peningkatan prevalensi stunting, yaitu pada tahun 2016 (25,5\%) dan meningkat di tahun 2017 (30,6\%) dengan prevalensi stunting di Kabupaten Padang Pariaman sebesar 33,6 persen. Angka tersebut hampir mendekati angka nasional 37,2 persen. ${ }^{5}$ Berdasarkan laporan dari Dinas Kesehatan Kabupaten Padang Pariaman tahun 2017, Kecamatan dengan angka stunting tertinggi adalah Kecamatan Lubuk Alung dengan ditemukannya 21,7 persen anak pendek dan 12,9 persen anak sangat pendek. Survei awal yang dilakukan terhadap 10 orang anak umur di bawah 2 tahun, dengan pengukuran tinggi badan (TB) dimana 3 orang anak di temukan pendek atau stunting, dengan hasil (z-score) -2 SD. 6

Komitmen yang telah dibangun pemerintah perlu di evaluasi dan salah satu instrumen yang menilai komitmen pemerintah terhadap masalah stunting dapat dilihat dengan The Hungger and Nutrition Commitment Index ( $\mathrm{HANCl})$. $\mathrm{HANCl}$ sendiri terdiri dari 2 sub Index yaitu Hunger Reduction Commitment Index ( $\mathrm{HRCl}$ ) dan Nutrition Commitment Index $(\mathrm{NCl})^{7} \mathrm{HRCl}$ lebih melihat kepada komitmen pemerintah dalam mengurangi kelaparan, sedangkan $\mathrm{NCl}$ lebih melihat kepada komitmen pemerintah dalam mengatasi masalah kekurangan gizi. Penelitian ini karena membahas stunting, peneliti lebih menfokuskan melihat satu sub index saja yaitu $\mathrm{NCl}$, alasan karena $\mathrm{NCl}$ melihat komitmen pemerintah dalam mengatatasi masalah kekurangan gizi. Stunting merupakan salah satu masalah kekurangan gizi. $\mathrm{NCl}$ terdiri dari 12 indikator diantaranya yaitu anggaran gizi, cakupan vitamin A, promosi MP-ASI, akses air bersih, akses sanitasi, kunjungan ibu hamil, fitur gizi dalam kebijakan pembangunan nasional, rencana gizi nasional, kerja sama multisektor, target program gizi, survei gizi nasional, dan aspek hukum. ${ }^{8}$

Berdasarkan uraian diatas, tingginya prevalensi stunting di Kabupaten Padang Pariaman menjadi masalah serius, oleh sebab itu peneliti tertarik untuk melakukan penelitian mengenai Analisis Komitmen Pemerintah Kabupaten Padang Pariaman dalam Mengatasi Masalah stunting berdasarkan Nutrition Commitment Index (NCI) Tahun 2018.

\section{METODE}

Penelitian ini menggunakan metode kualitatif dengan rancangan penelitian studi kebijakan (Policy study), skoring serta wawancara mendalam dengan informan. Informan dalam penelitian ini adalah ketua DPRD, Bupati, Kabid Sosial dan Budaya Bappeda, Kepala Dinas Kesehatan, Kasubag Perencanaan dan Penganggaran Dinas Kesehatan, Kasi Kesga dan Gizi Dinas Kesehatan, Pengelola Program Gizi Dinas Kesehatan, Kasi Promkes Dinas Kesehatan, Kasi Kesling Dinas Kesehatan, Kepala Puskemas Lubuk Alung dan Pemegang Program Gizi Puskesmas Lubuak Alung Kabupaten Padang Pariaman.

\section{HASIL}

Berikut hasil wawancara mendalam dan telaah dokumen dengan 11 responden yang dapat disajikan pada tabel dibawah ini. 
Tabel 1. Hasil triangulasi metode

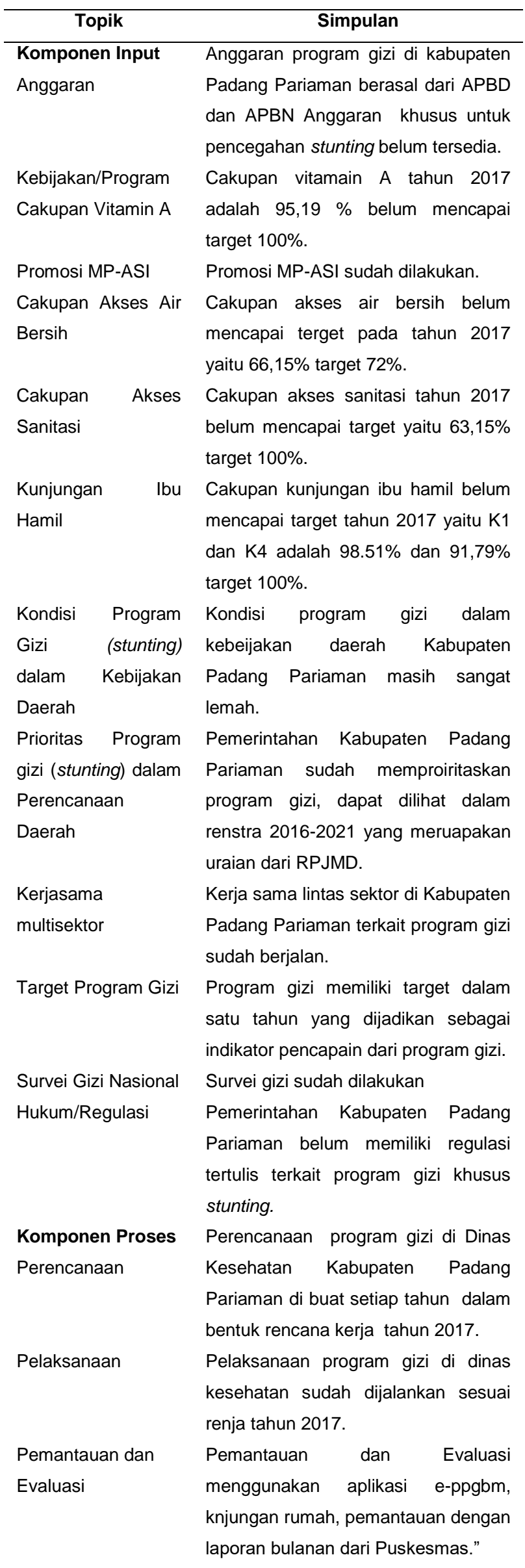

Tabel 2. Skor NCl di Kabupaten Padang Pariaman

\begin{tabular}{|c|c|c|}
\hline No & Topik & Skor NCl \\
\hline 1 & Pengeluaran/Anggaran & 0 \\
\hline 2 & Cakupan Vitamin A & 0 \\
\hline 3 & Promosi MP-ASI & 1 \\
\hline 4 & Akses Air Barsih & 0 \\
\hline 5 & Akses Sanitasi & 0 \\
\hline 6 & Kunjungan Ibu Hamil & 0 \\
\hline 7 & $\begin{array}{l}\text { Kondisi Program Gizi (Stunting) } \\
\text { dalam Kebijakan Daerah }\end{array}$ & 1 \\
\hline 8 & $\begin{array}{l}\text { Prioritas Program Gizi (Stunting) } \\
\text { dalam Perencanaan Daerah }\end{array}$ & 1 \\
\hline 9 & Kooordinasi Lintas Sektor & 1 \\
\hline 10 & Target Program Gizi (Stunting) & 1 \\
\hline 11 & Survei Gizi Dalam 3 Tahun Terakhir & 1 \\
\hline 12 & Peraturan/Regulasi & 0 \\
\hline & Total Skor & 6 \\
\hline
\end{tabular}

Hasil penilaian secara kualitatif terhadap 12 indikator $\mathrm{NCl}$ tersebut, diketahui enam indikator sudah dijalankan. Indikator tersebut adalah promosi MP-ASI, kondisi program gizi dalam kebijakan daerah, prioritas program gizi dalam perencanaan daerah, kerjasama multisektor, target program gizi, dan survei gizi nasional. Sedangkan indikator dengan skor 0 adalah indikator anggaran, cakupan vitamin A, cakupan akses air bersih, cakupan kunjungan ibu hamil dan regulasi / hukum .

\section{PEMBAHASAN}

Komponen input

\section{- Anggaran}

Anggaran untuk program gizi di Dinas Kesehatan Kabupaten Padang Pariaman masih belum cukup dan anggaran untuk kegiatan pencegahan stunting belum tersedia, sehinggan menyebabkan kegiatan belum berjalan maksimal. Ketidaktersedian anggaran untuk stunting merupakan masalah yang sekarang dihadapi oleh Dinas Kesehatan Kabupaten Padang Pariaman. Mengingat angka stunting di padang pariaman tahun 2017 sangat tinggi yaitu $33,6 \%$ yang hampir mendekati anggka nasional yaitu $37,2 \%{ }^{6}$ Hal ini sejalan dengan penelitian Wulandari (2013) menyatakan partisipasi anggaran signifikan positif terhadap kinerja pemerintah daerah, semakin tinggi partisipasi anggaran maka semakin tinggi juga kinerja aparat pemerintah. ${ }^{9}$ 
Mengatasi masalah keterbatasan anggaran, mestinya Dinas Kesehatan perlu melakukan advokasi kepada pemerintah daerah dan DPRD untuk mendapatkan dukungan dana dalam upaya pencegahan stunting di Padang Pariaman dan menyususn kegiatan pencegahan stunting seperti pelatihan dan pembinaan kader, sosialisasi stunting, pengadaan media promosi, kunjungan rumah untuk memantau ibu hamil dan bayi sampai umur 2 tahun yang dapat dilakukan oleh petugas kesehatan dan kader.

\section{- Kebijakan/Program}

a. Cakupan Vitamin A

Berdasarkan simpulan Tabel1 tentang cakupan vitamin A belum tercapai target di Padang Pariaman karena masih ada masyarakat yang enggan membawa anaknya ke posyandu karena minim pengetahuan ibu tentang pentingnya pemberian vitamin A pada anak. Hal ini disebabkan masih kurangnya sosialisasi dan pendekatan yang dilakukan oleh petugas kesehatan kepada ibu atau keluarga sasaran akan pentingnya pemberian vitamin $\mathrm{A}$. Kemudian belum maksimalnya upaya sweeping yang dilakukan petugas, sehingga masih ada sasaran yang tidak mendapatkan vitamin $\mathrm{A}$.

Penelitian ini sejalan dengan penelitian Indarwati (2015) menyatakan terdapat hubungan antara pengetahuan ibu dengan cakupan pemberian kapsul vitamin A pada balita di PKD Melati Sari Desa Durensari. ${ }^{10}$ Menurut Departemen Kesehatan tahun 2009, vitamin A merupakan salah satu zat gizi penting yang larut dalam lemak dan disimpan dalam hati, tidak dapat dibuat oleh tubuh, sehingga harus dipenuhi dari luar (esensial). Kebutuhan vitamin A yang dianjurkan untuk anak balita 250 mikrogram retinol (vitamin A) atau 750 mikrogram beta-karotin sehari. ${ }^{11}$ Menurut Kartasapoetra dan Marsetyo (1995), vitamin A adalah salah satu zat gizi yang berfungsi untuk penglihatan, fungsi kekebalan, pertumbuhan dan perkembangan serta reproduksi. Vitamin A berpengaruh terhadap sintesis protein, sehingga juga mempengaruhi pertumbuhan sel. Karena itulah, anak yang menderita defisiensi vitamin $\mathrm{A}$ akan mengalami kegagalan pertumbuhan. Kurang gizi mikro seperti
Zinc dan Vitamin A merupakan salah satu faktor yang mempengaruhi kejadian kurang gizi kronis (stunted). ${ }^{12}$

Pemecahan masalah tersebut, dinas kesehatan semestinya menindaklanjuti semua kendala yang ada melalui ikut serta dengan petugas puskesmas ke tempat sasaran untuk meyakinkan keluarga atau ibu sasaran yang anaknya tidak mau diberi vitamain $A$, dengan menjelaskan jika pemberian vitamin $A$ ini tidak berdampak buruk bagi kesehatan anak, justru vitamin A dapat meningkatkan kesehatan anak. Untuk petugas yang tidak melakukan sweeping agar diberikan teguran atau sanksi, sehingga petugas bisa komitmen dalam melaksanakan tugasnya dilapangan pada program pemberian vitamin $\mathrm{A}$.

\section{b. Promosi MP-ASI}

Kegiatan promosi MP-ASI sudah dilakukan tetapi belum berjalan dengan optimal disebabkan keterbatasan anggaran di dinas kesehatan untuk kegiatan promosi. Selain anggaran, kurang optimalnya promosi MP-ASI disebabkan masih kurangnya keaktifan petugas kesehatan dan kader dalam menyampaikan informasi ke masyarakat tentang pentingnya pemberian MP-ASI pada anak diatas 6 bulan. Kegiatan promosi hanya dilakukan pada saat posyandu dan kelas ibu hamil, informasi hanya di dapat bagi ibu yang datang ke posyandu.

Anggaran untuk kegiatan promosi di Dinas Kesehatan dari hasil telaah dokumen, pada tahun 2016 Rp.225.000.000 untuk semua kegiatan promosi dan pada tahun 2017 mengalami pengurangan Rp. 92.500.000. Anggaran untuk promosi ini digunakan untuk penyedian media promosi seperti leaflet, CD, spanduk dan penyuluhan. ${ }^{13}$ Anggaran untuk promosi masih kurang yang berdampak kurang makasimalnya kegiatan promosi di masyarakat. Penelitian ini sejalan dengan penelitian yang dilakukan oleh Alhamda (2012) ketersedian dana untuk promosi kesehatan di RSUD Kota Solok belum mencukupi. Dana untuk kegiatan tersebut sudah dianggarkan melalui APBD Provinsi Sumatera Barat, tetapi dalam pelaksanaan oleh tenaga promosi kesehatan belum mencukupi termasuk kekurangan alat media promosi dan juga kebutuhan sarana dan prasarana menyebabkan kegitan promosi tidak berjalan. ${ }^{14}$ 
Penelitian ini juga sejalan dengan yang dilakukan oleh Lestari (2014), menunjukan bahwa proporsi stunting lebih banyak terjadi karena anak tidak diberi ASI Eksklusif. Anak yang tidak diberi ASI Ekslusif memiliki resiko stunting 6,54 kali dibandingkan dengan anak yang diberi ASI Eksklusif. Selanjutnya anak yang diberi MP-ASI terlalu dini memiliki resiko menjadi stunting 6,54 kali dibandingkan dengan anak yang diberi MP-ASI sesuai dengan umur yang seharusnya. ${ }^{15}$ Hasil penelitian ini dapat disimpulkan kurangnya pengetahuan ibu tentang manfaaat ASI eksklusif dan manfaat MP-ASI pada anak, yang disebabkan kurangnya promosi tentang hal tersebut.

Peningkatan pengetahuan ibu tentang pentingnya MP-ASI di Kabupaten Padang Pariaman, dinas kesehatan melalui puskesmas perlu melibatkan kader terlatih dengan terlebih dahulu membekali kader dengan pelatihan dan pembinaan tentaang manfaat MP-ASI, sehingga kader bisa menjadi perpanjang tangan petugas kesehatan di lapangan untuk melakukan promosi MP-ASI pada masyarakat sekitar tempat tinggalnya agar memberikan MP-ASI yang sehat kepada anak dan diharapkan kader juga bisa memantau setiap sasaran yang diberikan MP-ASI. Dinas kesehatan harus melakukan advokasi ke pemerintah daerah untuk lebih meningkatkan anggaran untuk kegiatan promosi seperti anggaran untuk media promosi dan penyuluhan.

\section{c. Cakupan Akses Air Bersih}

Pencapaian cakupan akses air bersih di Kabupaten Padang Pariaman belum mencapai target yaitu sebesar $66,15 \%$ sedangkan target adalah $72 \%$ tahun 2017. Upaya yang sudah dilakukan adalah pemicuan, penyuluhan, pemeriksaan kualitas depot air minum, kualitas PDAM dan pemeriksan sumur masyarakat. Kendala yang ditemukan adalah masih banyak masyarakat yang belum memiliki akses air bersih yang layak, hal tersebut disebabkan oleh beberapa faktor seperti faktor ekonomi, perilaku dan pengetahuan masyarakat terhadap pentingnya menggunakan air besih yang memenuhi syarat kesehatan untuk keperluan rumah tangga. Sumber air bersih di Kabupaten Padang Pariaman terdiri dari; air PDAM, sumur, air hujan dan air sungai.
Cakupan air bersih yang belum tercapai di Padang Pariaman menyebabkan tingginya angka penyakit infeksi di masyarakat yang disebabkan oleh air yang tidak memenuhi syarat kesehatan. Berdasarkan hasil telaah dokumen angka penyakit diare pada anak di Padang Pariaman adalah 1.296 anak. ${ }^{16}$ Tingginya angka penyakit infeksi seperti diare dapat menjadi penyebab tingginya angka stunting di padang paraiaman. Anak yang sering mengalami penyakit infeksi dapat menghambat tumbuh kembang anak. Infeksi mempunyai konstribusi terhadap penurunan nafsu makan dan bila berlangsung secara terus menerus akan mengganggu pertumbuhan linier anak. ${ }^{17}$ Penelitian ini juga sejalan dengan penelitian Picauly dan Toy (2013) juga menunjukkan anak yang memiliki riwayat penyakit infeksi akan diikuti dengan peningkatan kejadian stunting sebesar 2,332 kali. $^{18}$

Permasalahan belum tercapainya target akses air bersih, dinas kesehatan harus berupaya lebih lagi dalam melakukan pendekatan kepada masyarakat melalui pemicuan, penyuluhan dan upaya promosi melalui pemasangan spanduk yang berhubungan dengan air bersih, sehingga bisa menarik dan menyadarkan masyarakat tentang pentingnya pemakaian air bersih untuk kehidupan mereka.

\section{d. Cakupan Akses Sanitasi}

Cakupan akses sanitasi di Kabupaten Padang Pariaman tahun 2017 adalah 63,15\% belum mencapai target (100\%). Kendala yang dihadapi adalah perilaku masyarakat yang sulit dirubah. Kegiatan yang dilakukan oleh dinas kesehatan untuk meningkatkan akses sanitasi adalah pemicuan dan penyuluhan. Penyebab belum tercapainya akses sanitasi masyarakat di padang pariaman adalah kurangnya kesadaran masyarakat untuk berperilaku hidup bersih dan sehat, tidak tersedia jamban sehat keluarga, ketidak tersedian akses air bersih yang layak, kurangnya pengelolaan limbah rumah tangga yang berefek pencemaran kepada lingkungan sekitar tempat tinggal. Berdasarkan hasil telaah dokumen 69.537 rumah tangga yang dipantau berPHBS, sebanyak $28,6 \%$ rumah tangga belum berPHBS.

Menurut Soetjiningsih (2013), sanitasi lingkungan memiliki peranan yang cukup dominan 
terhadap kesehatan anak dan tumbuh kembangnya. Kebersihan, baik kebersihan perorangan maupun lingkungan memegang peranan penting dalam menimbulkan penyakit. Kebersihan yang kurang dapat menyebabkan anak sering sakit misalnya diare, kecacingan, demam tifoid, hepatitis, demam berdarah. Demikian pula polusi udara yag berasal dari pabrik, asap kendaraan atau asap rokok dapat berpengaruh terhadap tingginya angka ISPA, tumbuh kembang anak yang sering mengalami penyakit akan terganggu. ${ }^{19}$ Penelitian Cahyono (2016) menyatakan bahwa sanitasi lingkungan yang buruk 3,978 kali beresiko stunting pada anak. Probabilitas atau peluang balita mengalami kejadian stunting karena sanitasi yang kurang baik adalah sebesar 1.381, artinya seorang balita dengan sanitasi lingkungan kurang, memiliki kemungkinan kejadian stunting 4 kali lebih besar dibandingkan dengan sanitasi lingkungan yang baik. ${ }^{20}$

Faktor sanitasi dan kebersihan lingkungan berpengaruh pula untuk kesehatan ibu hamil dan tumbuh kembang anak, karena anak usia di bawah dua tahun rentan terhadap berbagai infeksi dan penyakit. Paparan terus menerus terhadap kotoran manusia dan binatang dapat menyebabkan infeksi bakteri kronis. Infeksi tersebut, disebabkan oleh praktik sanitasi dan kebersihan yang kurang baik, membuat gizi sulit diserap oleh tubuh. Rendahnya sanitasi dan kebersihan lingkungan dapat memicu gangguan saluran pencernaan, yang membuat energi untuk pertumbuhan teralihkan kepada perlawanan tubuh menghadapi infeksi. ${ }^{21}$

Permasalahan belum tercapainya sanitasi lingkungan di Padang Pariaman, dinas kesehatan harus berupaya lebih lagi dalam melakukan pendekatan kepada masyarakat melalui pemicuan, penyuluhan dan upaya promosi melalui pemasangan spanduk yang berhubungan dengan PHBS, sehingga bisa menarik dan menyadarkan masyarakat tentang pentingnya PHBS dalam keluarga untuk mencegah penyakit yang di sebabkan dari kurang baiknya sanitasi lingkungan dan mengajak masyarakat untuk berperilaku hidup bersih dan meningkatkan kinerja petugas kesehatan dan kader kelapangan untuk melakukan pemantauan langsung kemasyarakat dan melakukan promosi langsung kepada masyarakat di sekitar tempat tinggal.

e. Kunjungan Ibu hamil

Capaian cakupan kunjungan ibu hamil $\mathrm{K} 1$ dan K4 di Kabupaten Padang Pariaman adalah 98.51\% dan K4 $91.79 \%$ masih dibawah target $100 \%$ pada tahun 2017. Upaya yang dilakukan adalah menjalankan program Padang Pariaman Sehat, dalam kegiatan tersebut dilakukan kunjungan minimal 5 $\mathrm{KK} /$ hari yang dilakukan oleh bidan desa akan tetapi kegiatan ini belum berjalan secara maksimal karena kurangnya keaktifan petugas kesehatan kelapangan dan mengaktifkan kader posyandu untuk memantau ibu hamil yang belum melakukan pemeriksaan ke puskesmas.

UNICEF (2012), intervensi untuk menurunkan anak pendek harus dimulai secara tepat sebelum kelahiran dengan pelayanan prenatal dan gizi ibu, dan berlanjut hingga usia dua tahun. Proses untuk menjadi seorang anak bertubuh pendek yang disebut kegagalan pertumbuhan dimulai dalam waktu rahim, hingga usia dua tahun. Pada saat anak melewati usia dua tahun, sudah terlambat untuk memperbaiki kerusakan pada tahun-tahun awal. Oleh karena itu, status kesehatan dan gizi ibu merupakan penentu penting tubuh pendek pada anak-anak. ${ }^{22}$

Dinas kesehatan harus lebih meningkatkan pemeriksaan kehamilan dengan meningkatkan kinerja petugas kesehatan, kader dan PWS agar benar-benar tahu tentang kondisi masyarakat tempat dia tinggal dan rutin melakukan kunjungan ketempat sasaransasaran yang ada dilokasi tempat tinggal mereka. Meningkatkan pengetahuan ibu dengan melakukan promosi-promosi baik secara penyuluhan maupun dengan menggunakan media.

\section{f. Kondisi Program Gizi (Stunting) dalam Kebijakan} Daerah

Berdasarkan hasil penelitian kondisi program gizi (stunting) dalam kebijakan pembangunan daerah Kabupaten Padang Pariaman masih sangat lemah. Lemahnya kondisi program gizi khusus stunting juga dapat dilihat dari satu pemegang kebijakan yang tidak tahu masalah stunting.Keterlibatan pemerintah daerah 
masih dalam bentuk kuratif yaitu dengan pemberian PMT pada balita dan ibu hamil KEK namun belum terlibat dalam upaya preventif dan promotif.

Kebijakan strategi pangan dan gizi merupakan acuan bagi seluruh stakeholders di tingkat pusat dan daerah, yang harus ditindaklanjuti dalam kebijakan/program yang operasional di propinsi dan kabupaten/kota sesuai dengan potensi dan kondisi wilayahnya masing-masing. ${ }^{23}$ Advokasi memang harus dilakukan dinas kesehatan kepada pemerintah daerah agar dukungan penuh dari pemerintah daerah benarbenar didapatkan. Pemerintahan Kabupaten Padang Pariaman harus lebih meningkatkan kondisi program gizi dalam kebijakan daerah, agar masalah gizi di Kabupaten Padang Pariaman dapat ditangani dengan baik untuk terwujudnya masyarakat yang sehat dan sejahtera.

\section{g. Prioritas Program gizi (stunting) dalam \\ Perencanaan Daerah \\ Hasil penelitian menunjukkan program gizi} merupakan salah satu program yang diprioritaskan oleh pemerintahan Kabupaten Padang Pariaman yang dituangkan dalam RPJMD dan menjadi dasar dinas kesehatan dalam penyusunan Renstra tahun 20162021. Program perbaikan gizi masyarakat sudah menjadi program prioritas yang dapat dilihat dari SKPD tahun 2017 dinas kesehatan dengan 4 kegiatan yaitu penyusunan peta informasi masyarakat kurang gizi, pemberian tambahan makanan dan vitamin kemudian kegiatan monitoring, evaluasi dan pelaporan. Akan tetapi proritas pemerintah daerah dalam mengatasi masalah stunting belum ada dikarenakan belum adanya program penanggulangan stunting di Kabupaten Padang Pariaman tahun 2017, pemerintah masih fokus pada masalah berat badan dan belum fokus pada masalah tinggi badan pada anak atau stunting. ${ }^{24}$

Penelitian ini juga sejalan dengan penelitian yang dilakukan oleh Rozi (2016) menyatakan pemerintahan Kota Bengkulu sudah memprioritaskan program gizi yang tertuang dalam RKPD Kota Bengkulu tahun $2015 .^{25}$ Padang Pariaman program gizi masyarakat juga sudah menjadi proritas perencanaan daerah Pemerintahan Kabupaten Padang Pariaman yang tertuang dalam RPJMD dan RENSTRA dinas kesehatan tahun 2016-2021. ${ }^{24}$

Harapan kepada Dinas Kesehatan Kabupaten Padang Pariaman agar menjadikan program stunting kedalam bagian program gizi yang diprioritaskan pelaksanaanya dan dimasukkan kedalam renstra Dinas Kesehatan Kabupaten Padang Pariaman, sejalan dengan itu dinas kesehatan juga tetap harus melakukan advokasi kepada pemerintah agar menjadikan program stunting menjadi program prioritas di Pemerintahan Daerah Kabupaten Padang Pariaman.

\section{h. Kerjasama multisektor}

Berdasarkan penelitian, kerja sama lintas sektor di Kabupaten Padang Pariaman terkait program gizi sudah berjalan. Lintas sektor yang terlibat adalah Bappeda, Dinas Pertanian, Dinas perternakan dan hewan, Dinas Sosial, Badan Ketahanan Pangan, Dinas PU, LH, Baznas, Kecamatan, Nagari dan Kaderkader gizi dia masyarakat. Berdasarkan hasil wawancara mendalam, saat ini kerjasama lintas sektor terhadap peneggulangan stunting kurang maksimal, dimana semua berjalan secara sendiri-sendiri dan tidak terkoordinasi sehingga capaian yang didapatkan tidak maksimal.

Stunting dapat merugikan ekonomi negara apabila terus dibiarkan tanpa ada penanggulangan. Untuk itu perlunya dukungan dari pemangku kepentingan pembangunan dan pembuat kebijakan serta pelaksana untuk berupaya menurunkan kejadian stunting dengan meningkat peran lintas sektor seperti Bappeda lebih memproritaskan penggaran stunting menjadi proritas Pemerintah Daerah Padang Pariaman, dinas pertaniaan dapat berperan meberikan dan memotivasi kepada masyarakat dalam mempertahankan kecukupan ketersedian pangan yang berdampak pada status gizi masyarakat, dinas pertenakan dan hewan dapat berperan melakukan upaya peningkatan pendapatan dan gizi masyarakat melalui usaha-usaha peternakan dengan memperhatikan dampak kesehatan yang mungkin timbul termasuk upaya penegahan stunting. 
Pemerintah Padang Pariaman juga dapat memaksimalkan pemanfaatan APBD dan dana alokasi khusus untuk program pelayanan intervensi gizi spesifik dan gizi sensitif, melalui proses penetapan DPA OPD dan mengalokasikan dana bantuan khusus bagi desa-desa yang kurang mampu dari aspek pendanaan, dalam upaya pencegahan stunting.

\section{i. Target Program Gizi}

Hasil dari penelitian Pemerintahan Kabupaten Padang Pariaman memiliki target untuk masalah stunting dapat diatasi kedepannya sesuai dengan target program gizi yang dibuat dinas kesehatan setiap tahunnya sehingga tidak ada lagi anak yang stunting. Akan tetapi target untuk menekan anggka stunting belum terlihat dilaporan, karena belum adanya target stunting kedepanya, akan tetapi dalam program gizi sudah termasuk dalam pencegahan stunting. Upaya yang dilakukan adalah meningkatkan kunjungan rumah dengan pemantauan program gizi, pemberian PMT pada balita dan ibu KEK, membentuk kelompok pendukung ASI, penyuluhan tentang ASI Ekslusif dan 1000 HPK.

Penelitian ini juga sejalan dengan penelitian dilakukan oleh Rozi (2016), Dinas Kesehatan Kota Bengkulu dalam menjalankan program gizi memiliki target dalam satu tahun yang dijadikan sebagai idikator pencapaian dari program gizi sehingga dapat dijadikan sebagai bahan eveluasi dan untuk menentukan alternatif pemecahan masalah pada perencanaan program gizi untuk tahun yang akan datang. ${ }^{25}$

Masalah stunting di Indonesia, pemerintah membentuk 100 Kabupaten/Kota prioritas untuk intervensi Anak kerdil (stunting). Kerangka intervensi yang dilakukan pemerintah Indonesia adalah intervensi gizi spesifik dan intervensi gizi sensitif, dimana untuk intervensi gizi spesifik ini lebih ditujukan kepada anak dalam 1.000 Hari Pertama Kehidupan (HPK) yang mana dapat berkontribusi $30 \%$ penurunan stunting yang dilakukan pada sektor kesehatan dan bersifat jangka pendek serta hasilnya dapat dicatat dalam waktu relatif pendek. Sedangkan intervensi gizi sensitif lebih lebih berfokus pada pembangunan diluar sektor kesehatan tetapi dapat berkontribusi pada $70 \%$ intervensi stunting dan biasanya dilakukan secara lintas kementrian dan lembaga. ${ }^{26}$

Adanya target kedepannya tentang pengendalian masalah gizi di Padang Pariaman merupakan suatu bentuk komitmen dari pemerintah dalam meningkatkan status gizi dimasyarakat. Selain itu dinas kesehatan seharusnya juga mebentuk target untuk pengendalaian stunting, agar masalah stunting yang tinggi di padang pariaman dapat ditekan dan tidak ada lagi anak yang mengalamai stunting dengan meningkatkan kinerja dinas kesehatan dan sektorsektor lain serta dukungan yang kuat dari pemangku kebijakan seperti Bupati dan DPRD.

\section{j. Survei Gizi Nasional}

Berdasarkan hasil penelitian Dinas Kesehatan Kabupaten Padang Pariaman sudah melakukan survei gizi melalui kegiatan PSG yang dilakukan 2 kali dalam setahun, penimbangan masal, dan untuk sekarang bentuk survei dari dinas kesehatan yaitu dalam aplikasi e-PPGBM yaitu pemantauan dan pelaporan gizi masyarakat dengan sistem online yang bersamaan dengan program Padang Pariaman Sehat dengan melakukan kunjungan minimal $5 \mathrm{KK} /$ Hari yang dilakukan oleh bidan desa.

Riskesdas tahun (2013) merupakan kegiatan riset kesehatan berbasis masyarakat yang dapat digunakan untuk mengevaluasi perubahan status kesehatan di tingkat Kabupaten/Kota, Provinsi dan Nasional termasuk indikator MDGs bidang kesehatan. Hasil Riskesdas 2013 menunjukkan peningkatan PTM dan masih tingginya masalah gizi di masyarakat yang diduga berkaitan dengan perubahan pola konsumsi makanan di masyarakat. ${ }^{4}$

Proses survei gizi yang dilakukan mestinya selalu dilakukan monitoring dilakukan terhadap program tersebut, dan meningkatkan motivasi petugas dalam pelaksanaan survei gizi, untuk petugas yang tidak menjalankan program survei gizi secara maksimal dan tidak bisa mencapai target mestinya Dinas Kesehatan bisa melakukan pembinaan dan memberikan sanksi, agar petugas sadar bahwa survei gizi yang dilakukan sangat penting dilakukan. 


\section{Hukum/Regulasi}

Pemerintahan Kabupaten Padang Pariaman belum memiliki regulasi tertulis terkait program gizi khusus stunting. Untuk pelaksaanan program gizi saat ini mengacu pada Undang-Undang Kesehatan No 36 Tahun 2009 dan Permenkes No 23 tahun 2014 tentang upaya perbaikan gizi. Kegiatan perbaikan gizi dijalankan sesuai dengan Renstra dinas kesehatan tahun 2016-2021. Peraturan berupa undang-undang yang merupakan dasar hukum, diperlukan untuk melindungi serta menjamin kesehatan bagi setiap rakyat Indonesia tanpa diskriminasi, termasuk tersangka/terdakwa. Undang- undang No. 36 Tahun 2009 tentang Kesehatan merupakan cerminan produk hukum yang menjadi payung hukum dan dasar hukum bagi tenaga pelayanan kesehatan masyarakat. ${ }^{27}$ Terkait upaya untuk mengurangi serta menangani pervalensi stunting, pemerintah di tingkat nasional telah mengeluarkan beberapa regulasi yang diharapkan dapat berkontribusi pada penanggulangan prevalensi stunting.

Proses regulasi dapat berjalan lancar jika didahului dengan advokasi yang dilakukan oleh dinas kesehatan kepada Pemerintah Kabupaten Padang Pariaman, advokasi sekaligus sosialisasi kepada Bupati dengan tujuan untuk menjelaskan bahwa masalah stunting merupakan masalah yang tidak bisa dianggap sepele dan memerlukan peran serta dari pemerintah untuk mengatasi permasalahan tersebut, peran serta yang diharapkan berupa dukungan melalui terbitnya Peraturan Bupati yang didalamnya mengatur tentang mekanisme pelaksanaan penanggulangan masalah stunting di Kabupaten Padang Pariaman dan membebankan anggaran kepada APBD Pemerintah Kabupaten Padang Pariaman.

Regulasi/hukum terkait stunting sangat diperlukan sebagai pedoman dalam penanggulangan stunting. Tidak adanya regulasi atau peraturan bupati (perbub) tentang program gizi membuat kegiatan dalam pencegahan penanggulangan masalah gizi seperti stunting masih sangat lemah yang meyebabkan kurangnya tanggung jawab petugas kesehatan dalam menangani masalah gizi tersebut. Dengan adanya perbub dapat menjadi suatu bentuk komitmen pemerintah dalam mengatasi masalah gizi di daerah tersebut. Oleh sebab itu Pemerintah
Kabupaten Padang Pariaman diharapkan dapat menyusun peraturan daerah seperti perbub Bupati tentang penanggulangan gizi dan stunting agar kegiatan bisa berjalan dengan adanya peraturan tersebut.

\section{Komponen Proses}

\section{a. Perencanaan}

Perencanaan program gizi di Dinas Kesehatan Kabupaten Padang Pariaman dibuat setiap tahun dalam bentuk rencana kerja berdasarkan Renstra dinas kesehatan tahun 2016-2021, dengan melakukan analisis, identifikasi permasalahan dari evaluasi pencapaian sebelumnya dan menurut prioritas masalah yang telah ditentukan sesuai dengan analisis masalah dan melibatkan lintas sektor. Perencanaan kegiatan terdiri dari penyususnan peta informasi masyarakat kurang gizi, pemberian tambahan makanan dan vitamin, pemberdayaan masyarakat untuk pencapaian keluarga sadar gizi, monitoring, evaluasi dan pelaporan.

Penelitian ini sejalan dengan penelitian Rozi (2016) Perencanaan program gizi yang dilakukan Dinas Kesehatan Kota Bengkulu dalam bentuk rencana kerja tahunan yang mengacu pada Rencana Strategis Tahun 2013-2018, dimana perencanaan ini dibuat berdasarkan hasil analisis, identifikasi permasalahan dari evaluasi pencapaian program pada tahun sebelumnya. $^{25}$

Adanya perencanaan program gizi yang dibuat oleh dinas kesehatan seharusnya menjadi acuan kedepannya bagi petugas kesehatan dan pemegang program gizi dalam penanggulangan masalah gizi di masyarakat. Perencanaan yang telah dibuat seharusnya dapat dijalankan sesuai target yang sudah ditetapkan oleh kementerian kesehatan. Dinas kesehatan seharusnya juga membentuk perencanaan tentang pengendalian stunting karena stunting merupakan program prioritas pembangunan nasional.

\section{b. Pelaksanaan}

Pelaksanaan program gizi di Dinas Kesehatan Kabupaten Padang Pariaman sudah dijalankan sesuai renja tahun 2017 . Kegiatan yang dilaksanakan adalah pemantauan status gizi, penimbangan masal, pemberian vitamin A, pemberian PMT yang dipantau 
oleh kepala dinas kesehatan. Kendala dalam pelaksanaan adalah anggaran, sehingga kegiatan tidak berjalan dengan baik, seperti upaya preventif dan promotif. Hasil telaah dokumen kegiatan program gizi tahun 2017 yang terdiri dari 18 kegiatan 13 kegiatan sudah mencapai target.

Penelitian ini sejalan dengan studi Rozi (2016) yang menyatakan dalam pelaksanaan program gizi Kota Bengkulu terdiri dari penanggulangan gizi buruk di TFC, pemberian makanan tambahan, disiminasi informasi, pertemuan verifikasi informasi, pemantauan garam beryodium, pembinaan kelompok pendukung ASI dan pameran gizi mendapatkan dukungan yang baik dari walikota dan kepala dinas, sedangkan kendala yang dihadapi adalah alokasi dana yang masih terbatas sehingga belum ada upaya preventif dan promotif. ${ }^{25}$

Angka stunting di Padang Pariaman ditekan oleh Dinas Kesehatan seharusnya memberikan peran dalam pelaksanaan penaggulangan stunting seperti meningkatkan sosialisasi kebijakan pencegahan stunting pada masyarakat dan stake holder lain, pembinaan pada UPT dalam peningkatan status dan gizi masyarakat, melaksanakan strategi promosi kesehatan, mengembangkan sistem surveilens gizi, meningkatkan pemberian suplemen gizi pada ibu hamil dan balita, meningkatkan pelayanan persalinan di fasyankes, berkoordinasi dengan dinas PU dalam pelaksanaan program STBM dan pemberian obat cacing pada pada anak yang dapat mencegah stunting.

\section{c. Pemantauan dan Evaluasi}

Pemantauan dan evaluasi yang dilakukan Dinas Kesehatan Kabupaten Padang Pariaman adalah pemantauan dengan menggunakan apalikasi $\mathrm{E}$ PPGBM dimana dalam kegitan ini petugas pegelola program gizi puskesmas melakukan pelaporan dalam bentuk aplikasi apabila ditemukan dari kunjungan rumah atau petemuan di posyandu balita yang mengalami masalah gizi, maka data tersebut langsung di input ke aplikasi tersebut, kegiatan pelaporan ini dilakukan setiap hari.

Penelitian ini juga sejalan dengan penelitian Rozi (2016) Pemantauan dan evaluasi program gizi
Dinas Kesehatan Kota Bengkulu dilakukan melalui kegiatan rapat bulanan dan akhir tahun, evaluasi dilakukan terhadap pencapaian target yang sudah ditetapkan dalam Rencana Strategis Tahun 20132018. ${ }^{25}$ Menurut Depkes RI (2009) kegiatan monitoring ditujukan pada pemantauan pelaksanaan kegiatan sehari-hari termasuk penyelesaian pengaduan masyarakat dan kegiatan. Sedangkan evaluasi berupa suatu kegiatan pencatatan dan pelaporan kegiatan secara berkesinambungan untuk meningkatkan kinerja berikutnya laporan basil kegiatan dilakukan analisis hasil kegiatan. ${ }^{27}$

Harapan agar Dinas Kesehatan Padang Pariaman menganggarkan dana untuk melakukan monitoring dan evaluasi dalam pelaksanaan perbaikan program gizi secara periodik setiap bulannya, dan melakukan observasi serta melakukan wawancara terhadap petugas puskesmas maupun masyarakat masalah apa yang muncul dari program tersebut dan dibuat dalam bentuk laporan serta dapat dipertanggung jawabkan.

\section{Komponen Output \\ Skor $\mathrm{NCl}$}

Hasil penilaian secara kualitatif terhadap 12 indikator $\mathrm{NCl}$ tersebut, diketahui 6 indikator sudah dijalankan, berarti komitmen Pemerintah Daerah Padang Pariaman terhadap masalah stunting sudah cukup baik, tetapi masih perlu peningkatan untuk indikator-indikator yang tidak tercapai seperti indikator anggaran, cakupan vitamin A, cakupan akses air bersih, cakupan kunjungan ibu hamil dan regulasi / hukum tertulis.

Penelitian ini sejalan dengan penelitian yang dilakukan oleh Rozi (2015) skor NCl Kota Bengkulu adalah 9. diantaranya adalah anggaran belum cukup, akses air bersih belum mencapai target, akses saitasi belum mencapai target, kunjungan ibu hamil yaitu $\mathrm{K} 1$ dan K4 belum mencapai terget dan dan tidak ada peraturan/regulasi tertulis (Perda Kota Bengkulu) tentang perbaikan gizi. ${ }^{25}$

Nutrition Commitment Index (NCl) adalah indeks untuk mengukur komitmen politik pemerintah dalam mengatasi kekurangan gizi dengan 12 indikator yang berkaitan dengan komitmen untuk mengatasi 
kelaparan dan kekurangan gizi yang dikelompokkan dalam 3 tema yaitu hukum, kebijakan/program dan pengeluaran/anggaran. ${ }^{8}$

Indonesia termasuk dalam komitmen menengah yaitu peringkat 12 dari 45 negara untuk $\mathrm{HANCl}$ dan peringkat \& untuk NCl. Dari 12 indikator, terdapat 2 indikator komitmen pemerintah dalam mengatasi masalah gizi dengan skor rendah yaitu pada indikator cakupan vitamin A (76\%) dan indikator akses terhadap air minum bersih $(84,3 \%)$, selain itu terdapat 2 indikator dengan skor sangat rendah yaitu pada indikator akses sanitasi $(58,7 \%)$ dan indikator fitur gizi dalam kebijakan pembangunan nasional masih lemah. ${ }^{8}$

Peningkatan hasil pencapaian indikator yang maksimal, diharapkan adanya komitmen yang kuat dari Pemerintah Daerah Kabupaten Padang Pariaman terhadap upaya penanggulangan masalah stunting, komitmen yang diharapkan berupa adanya peraturan Bupati khusus penanggulangan masalah stunting, adanya dukungan dana untuk pelaksanaan kegiatan penanggulangan stunting dan adanya komitmen dari pemerintah daerah untuk memperkuat koordinasi antara instansi atau sektor-sektor yang perlu dilibatkan dalam mengatasi masalah stunting di Kabupaten Padang Pariaman.

\section{SIMPULAN}

Hasil penilaian secara kualitatif terhadap 12 indikator $\mathrm{NCl}$ diketahui 6 indikator sudah dijalankan, berarti komitmen Pemerintah Daerah Padang Pariaman terhadap masalah stunting sudah cukup baik, tetapi masih perlu peningkatan untuk indikatorindikator yang tidak tercapai. Hasil ini didukung dengan hasil penskoran yang dilakukan, Indikator yang berjalan dinilai dengan nilai 1 , indikator tersebut adalah promosi MP-ASI, kondisi program gizi dalam kebijakan daerah, prioritas program gizi dalam perencanaan daerah, kerjasama multisektor, target program gizi, dan survei gizi nasional. Sedangkan indikator dengan skor 0 adalah indikator anggaran, cakupan vitamin A, cakupan akses air bersih, cakupan kunjungan ibu hamil dan regulasi / hukum tertulis.

\section{SARAN}

Disarankan Pemerintah Kabupaten Padang Pariaman hendaknya ikut terlibat dalam penanggulangan masalah stunting dengan memaksimalkan koordinasi ke sektor lain dan Dinas Kesehatan lebih memperkuat kerjasama lintas sektor yang berhubungan dengan perbaikan gizi masyarakat guna menekan angka stunting di Padang Pariaman.

\section{UCAPAN TERIMA KASIH}

Terima kasih kepada seluruh pihak yang turut membantu dalam menyelesaikan penelitian ini.

\section{DAFTAR PUSTAKA}

1. World Health Organization (WHO). Global nutrition monitoring framework operational guidance for tracking progress in meeting target For 2025. WHO.hlm.24-9.

2. Badan Penelitian dan Pengembangan Kesehatan (Balitbangkes) Republik Indonesia. Pendek (stunting) di Indonesia, masalah dan solusinya. Jakarta: Lembaga Penerbit Balitbangkes.2015;1-2.

3. Mitra. Permasalahan anak pendek (stunting) dan intervensi untuk mencegah terjadinya stunting (suatu kajian kepustakaan). Jurnal Kesehatan Komunitas. 2015;2:254-61.

4. Badan Penelitian dan Pengembangan Kesehatan Republik Indonesia. Riset Kesehatan Dasar. 2013. Jakarta: Balitbangkes. 2013.hlm.1-281.

5. Dinas Kesehatan Provinsi Sumatera Barat. Laporan pemantauan status gizi tahun 2015-2017. Dinas Kesehatan Provinsi Sumatera Barat.2017.

6. Dinas Kesehatan Kabupaten (DKK) Padang Pariaman. Laporan pemantauan dan pelaporan gizi berbasis masyarakat tahun 2017. DKK Padang Pariaman. 2017.

7. Lintelo DJH, Haddad LJ, Lakshman R, Gatellier K. The hunger and nutrition commitment index (HANCl 2011). England: Institute of Development Studies. 2012.hlm.12-4

8. Lintelo DJH, Haddad LJ, Lakshman R, Gatellier K. The hunger and nutrition commitment index (HANCI 2013). England: Institute of Development Studies. 2014.hlm.8-13. 
9. Wulandari N. Pengaruh partisipasi anggaran dan komitmen organisasi terhadap kinerja aparat pemerintah daerah. Jurnal Akuntansi. 2013;1(1):714.

10. Indarwati E. Hubungan tingkat pengetahuan ibu dengan cakupan pemberian vitamin A pada balita di PKD Melati Sari Desa Durensari Kecamatan Bagelen Kabupaten Purwerejo. Jurnal Komunikasi Kesehatan. 2015;6(1):1-2.

11. Departemen Kesehatan (Depkes) Republik Indonesia. Panduan manajemen suplemen vitamin A. Jakarta: Direktorat Bina Gizi Masyarakat (Depkes). 2009;5-12.

12. Kartasapoetra, Marsetyo. IImu gizi korelasi gizi kesehatan dan produktivitas kerja. Jakarta: Rineka Cipta.1995;34-5.

13. Dinas Kesehatan Kabupaten (DKK) Padang Pariaman. Dokumen pelaksanaan anggaran satuan kerja perangkat daerah pemerintahan Kabupaten Padang Pariaman tahun 2017. DKK Padang Pariaman; 2017.

14. Alhamda S. Analisis kebutuhan sumber daya promosi kesehatan di rumah sakit umum daerah Solok. Jurnal Manajemen Pelayanan Kesehatan. 2012;15(2):77-85.

15. Lestari W. Faktor risiko stunting pada anak umur 624 bulan di Kecamatan Penanggalan Kota Subulussalam Provinsi Aceh. Jurnal Gizi Indonesia. 2014;3(1):37-45.

16. Dinas Kesehatan Kabupaten (DKK) Padang Pariaman. Profil dinas kesehatan tahun 2017. DKK Padang Pariaman. 2017.

17. Dwi BW, Wirjatmadi RB. Beberapa faktor yang berhubungan dengan status gizi balita stunting. The Indonesian Journal Of Public Health. 2012; 8(3):99-104.
18. Picauly I, Toy SM. Analisis determinan dan pengaruh stunting terhadap prestasi belajar anak sekolah di Kupang dan Sumba Timur,NTT. J. Gizi Pangan .2013;8(1):55-62.

19. Soetjiningsih. Tumbuh kembang anak. Jakarta: EGC.2013,hlm.54.

20. Cahyono F. Faktor penentu stunting anak balita pada berbagai zona ekosistem di Kabupaten Kupang. Jurnal Gizi dan Pangan. 2016;11(1):12-3.

21. Millenium Challenge Account Indonesia. Stunting dan masa depan Indonesia: Millenium Challenge Corporation United States Of America. 2014. hlm.2.

22. United Nation Emergency Children's Fund. Ringkasan kajian gizi. Jakarta: Pusat Promosi Kesehatan-Kemenkes Rl;2012.hlm.3-4.

23. Kementrian Pertanian Republik Indonesia. Kebijakan strategi pangan dan gizi tahun 20152019. Jakarta: Kementrian Pertanian Republik Indonesia. 2015;12-8.

24. Dinas Kesehatan Kabupaten (DKK) Padang Pariaman. Rencana startegis dinas kesehatan tahun 2016-2021. DKK Padang Pariaman;2018.

25. Rozi VF. Analisis komitmen pemerintah kota bengkulu dalam mengatasi masalah gizi berdasarkan nutrition commitment index ( $\mathrm{NCl}$ ). [tesis]. Padang: Pascasarjana Kesehatan Masyarakat Universitas Andalas; 2016.

26. Tim Percepatan Penanggulangan Kemiskinan. 100 Kabupaten/Kota prioritas untuk intervensi anak kerdil (sunting). Jakarta: 2017;2-5.

27. Kementerian Kesehatan (Kemenkes) RI. Undangundang kesehatan no.36 tahun 2009 tentang kesehatan. Jakarta: Kemenkes RI; 2009. 